\section{Luther A. Allen}

Luther A. Allen, born 1921, died Feb. 27, 1998, was a good political scientist; more important, he was a good person, whose presence enriched a host of students and friends. Born in Plattsburgh, New York, he was educated at Williams College, Iowa State University, and the University of Chicago, where he earned a Ph.D. in international relations. He first visited Europe in 1939 with a student travel association, confirming his intention to devote his life to the study and teaching of international relations. He served in the armed forces during World War II in England and France, where, an unlikely enlisted man, he struck up friendships with such figures as Noel Brailsford and Jacques (Duchamp) Villon. He joined the faculty of the University of Massachusetts, Amherst in 1952, retired in 1985, and moved to Montreal, Quebec, where he died suddenly while swimming.

At the University of Massachusetts he played a major role in the department's undergraduate program, organized and moderated public radio broadcasts of the "Great Decisions" program for years, and lived as Professor in Residence in the Orchard Hill residential education program (1964-85), which he helped shape into a real living/learning environment. In 1985 he was awarded a University Chancellor's Medal for Distinguished Service as "scholar, educator, and mentor."

Throughout his career he had a special interest in French politics and visited France regularly. In 1944 the young soldier wrote home: "I arrive in Paris. What a city! What color and vitality. So urban, modern, beautiful.... I am so anxious to get out and take it all in." And indeed he did over the next fifty years. These visits fed not only his interest in French politics, but his love of the language and of cathedrals (an aesthetic rather than a religious passion). At the time of his death, he had just returned, full of enthusi- asm, from a trip to Paris. To his sensitive love of architecture and art was joined a love of music that he himself called "obsessive." Flowing from his knowledge of France and international politics, in the late 1950 s and early 1960 s he closely followed Vietnamese affairs and was visiting professor at Saigon University, Vietnam. He was involved in efforts there and in the U.S. to build a liberal democratic regime. Failed efforts, he recognized.

After retirement he was active in Montreal politics of planning, and published essays on new towns and urban planning. He championed preservation of the Mount Royal Park and, at the time of his death, was preparing a study on the work of Frederick Law Olmstead. He was a sympathiser with Francophone political efforts, though always the astute political commentator who could chuckle at anyone's foolish excesses. His phone answering machine spoke first its "Bonjour" message, then its equally warm welcome of "Hi, Anglos!"

In May 1998, a memorial service was held on campus, with family, friends, colleagues, students, and a student string quartet (which we believe would specially have pleased him). Jean Elshtain affectionately wrote: "Luther was the gentlest of men and a sprite in the form of an academician." The occasion formally ended: "remembering in awe, in joy and sorrow, a good man's rich and other-enriching life. We shall never again know such a one as Luther."

Lewis C. Maizner

University of Massachusetts, Amherst

\section{Robert H. Dix}

Robert H. Dix died on October 3, 1998, in Houston, Texas, at the age of 68 , from complications arising from multiple sclerosis and cancer. Bob carried on courageously as an inspiring teacher and exacting scholar long after his disease had left him in a wheelchair.

Bob earned a B.A. and M.A. at
Harvard, then entered the Foreign Service. After a tour of duty in Bogota, Colombia, he chose to leave the Foreign Service and pursue his passion for Latin America in an academic setting. He returned to Harvard for a Ph.D., taught political science at Yale from 1962-66, then, in 1968, after a year of research in Chile, and another as associate at the Harvard Center for International Affairs, joined the political science department at Rice University, where he served until retirement in 1994. From 1987 to 1994 he was the Lena Gohlman Fox Professor of Political Science.

As a Latin Americanist, Bob is perhaps best known for his work on Colombia, including two books, Colombia: The Political Dimensions of Change (Yale, 1967), and The Politics of Colombia (Praeger, 1987), and a number of articles. He also had a close familiarity with politics and society in other Latin American countries. In 1985 he received the Hoover Institution Prize for the best article of the year on Latin American politics.

As a political scientist, Bob sought to make sense of the Latin American experience in four broad areas: political parties, populism, revolutionary movements, and the conditions of democracy. Using some of the theories and methods of mainstream political science, combined with an extensive knowledge of Latin America, he made important contributions to our understanding of the conditions under which revolutions succeed, populist movements emerge, and democracies take hold. He wrote the chapter on Latin America in Robert Dahl's Regimes and Oppositions (Yale, 1967). It is noteworthy that one of his last publications, building on his work with Latin American revolutions, dealt with the overthrow of communism in Eastern Europe. His life and work serve as clear evidence that area expertise and a commitment to political science as a discipline need not be mutually exclusive. Indeed, 